ВПЛИВ ЕКСПЕРИМЕНТАЛЬНОГО АЛОКСАНОВОГО ДІАБЕТУ НА МОРФОЛОГІЮ ЛЕГЕНЕВИХ СТРУКТУР ЩУРІВ ВІКУ ПРОГРЕСИВНОГО РОСТУ

\title{
Т.П. Теслик
}

Сумський державний університет, медичний інститут, м. Суми, Україна

Ключові слова: легені, алоксановий діабет, міжальвеолярна перегородка, респіраторна бронхіола.

Буковинський медичний вісник. T.22, № 2 (86). C. $90-95$.

DOI:

10.24061/2413-0737.

XXII.2.86.2018.39

\section{E-mail:}

tesluk.tanya@ukr.net
Мета роботи - дослідити зміни морфологічних структур легеневої тканини шурів віку прогресивного росту в умовах експериментального алоксанового діабету.

Матеріал і методи. Дослідження проведені на 48 білих лабораторних щурах обох статей, масою 170,1土0,13 г. Тварини були роподілені таким чином на групи (у кожній знаходилось по 6 особин) - 1-ша з терміном алоксанового діабету 90 діб, 2-га - 120 діб, 3-тя - 150 діб, 4-та 180 діб. Кожна вищевказана експериментальна група порівнювалась з відповідною інтактною.

Для експериментального моделювання гіперглікемії використовували хімічну сполуку - алоксан. Забій шести щурів кожної вікової групи проводили кожні 30 днів шляхом розтину грудної клітки під внутрішньоочеревинним тіопентал-натрієвим наркозом.

Використані такі методи дослідження легеневої тканини: гістологічне дослідження із забарвленням за Ван-Гізон, скануюча електронна мікроскопія і морфометрія за допомогою програми Digimizer 2007.

Результати. Проводячи аналіз отриманих даних по щурах інтактної групи в розрізі їх вікових змін (проводили дослідження щурів молодого віку з п'яти до восьми місяиів), можна дійти таких висновків, щзо з віком товщина міжальвеолярної перегородки (ТМП) і ширина провідного відділу респіраторної бронхіоли (ШПБ) збільшуються. Зі збільшенням терміну експериментального иукрового діабету, збільшується ширина провідної бронхіоли (ПБ). Якщзо на 90-ту добу експерименту ШПБ становить 63,54 \pm 0,5 мкм, то вже на 180-ту - 95,02 \pm 0,6 мкм (зростання показника на 49,5\% ( $\leq 0,001)$. Встановлено, щуо наявність хронічної гіперглікемії прямо пропориійно впливає на гіпертрофію міжальвеолярної перегородки. ТМП на 90-ту добу експерименту становить 7,03 \pm 0,1мкм, а вже на 180-ту добу - 15,02 \pm 0,04 мкм (зростання показника у 2 рази). Висновки. Таким чином, за умов експериментального алоксанового діабету виникає потовщення міжальвеолярних перегородок, щчо можна пов 'язати з гіперплазією та гіпертрофією колагенових волокон; збільшення ширини провідного відділу респіраторної бронхіоли, щзо говорить про бронходилатацію та, опосредковано, про емфізематозні зміни у легенях. Тобто, хронічна гіперглікемія провокує розвиток порушення дихального акту за рестриктивним типом із паралельним розвитком компенсаторної емфіземи.

\section{ВЛИЯНИЕ ЭКСПЕРИМЕНТАЛЬНОГО АЛЛОКСАНОВОГО ДИАБЕТА НА МОРФОЛОГИЮ ЛЕГОЧНЫХ СТРУКТУР КРЫС ВОЗРАСТА ПРОГРЕССИВНОГО РОСТА}

Т.П.Теслык

Цель исследования - исследовать изменения морфологических структур легочной ткани крыс прогрессивного роста в условиях экспериментального аллоксанового диабета.

Материал и методы. Исследования проведены на 48 бельх лаборатор- 
Буковинский медициинский вестник. T.22, № 2 (86). C. 90-95.
Key words: lungs, alloxan diabetes, interalveolar septum, respiratory bronchioles.

Bukovinian Medical Herald. V.22, № 2 (86). P. 90-95. ных крысах обоего пола, массой 170,1 \pm 0,13 г. Животные были разделень следующим образом на группы (в каждой находилось по 6 особей) - 1-я со сроком аллоксанового диабета 90 суток, 2-я - 120 суток, 3-я - 150 суток, 4-я - 180 суток. Каждая вышеуказанная экспериментальная группа сравнивалась с соответствуюшей интактной.

Для экспериментального моделирования гипергликемии использовали химическое соединение - аллоксан. Забой шести крыс каждой возрастной группы проводили каждые 30 дней путем вскрытия грудной клетки под внутрибрюшинным тиопентал-натриевым наркозом.

Использованы следуюшче методы исследования легочной ткани: гистологическое исследование с окрашиванием по Ван-Гизон, сканирующая электронная микроскопия и морфометрия с помощьью программы Digimizer 2007.

Результаты. Проводя анализ полученных данных по крысам интактной группь в разрезе их возрастных изменений (проводили исследования крыс молодого возраста с пяти до восьми месяцев), можно сделать следующчие заключения: с возрастом толщчина межальвеолярной перегородки (ТМП) и иирина проводного отдела респираторной бронхиоль (ШПБ) увеличиваются. С увеличением срока экспериментального сахарного диабета увеличивается ширина проводящуей бронхиоль (ПБ). Если на 90-е сутки эксперимента ШПБ составляет 63,54 \pm 0,5 мкм, то уже на 180-е-95,02 \pm 0,6 мкм (возрастание показателя на 49,5\% ( $\leq \leq 0,001)$. Установлено, что наличие хронической гипергликемии прямо пропоричинально влияет на гипертрофию межальвеолярной перегородки. ТМП на 90-е сутки эксперимента составляет 7,03 \pm 0,1 мкм, а уюе на 180-е сутки - 15,02 0,04 мкм (возрастание показателя в 2 раза). Выводы. Таким образом, в условиях экспериментального аллоксанового диабета возникает утолщение межальвеолярной перегородки, что можно связать с гиперплазией и гипертрофией коллагеновых волокон; увеличение ширины проводного отдела респираторной бронхиоль, что говорит о бронходилатации и, опосредованно, о эмфизематозных изменения в легких. То есть, хроническая гипергликемия провоцирует развитие нарушения дыхательного акта по рестриктивному типу с параллельным развитием компенсаторной эмфиземы.

\section{THE EFFECT OF EXPERIMENTAL ALOXANE-INDUCED DIABETES ON THE MORPHOLOGY OF PULMONARY STRUCTURES IN RATS OF THE PROGRESSIVE GROWTH AGE T.P Teslyk}

Objective - to study the changes in the morphological structures of pulmonary tissue in rats of progressive growth under conditions of experimental aloxane-induced diabetes.

Material and methods. The study involved 48 white laboratory rats of both sexes, with a mass of $170.1 \pm 0.13 \mathrm{~g}$. The animals were divided into groups as follows (each containing 6 individuals) - the 1st with the duration of aloxan diabetes 90 days, the $2 n d-120$ days, the third - 150 days, the 4 th - 180 days. Each of the above experimental groups was compared with the corresponding intact one.

For experimental modeling of hyperglycemia, a chemical compound called alloxane was used. A slaughter of six rats of each age group was performed every 30 days by opening the thorax under intraperitoneal thiopental sodium narcosis. 
The following methods for studying pulmonary tissue were used: histological examination with painting by Van Nizon, scanning electron microscopy and morphometry using the Digimizer 2007 program.

Results. Carrying out the analysis of the obtained data on rats of the intact group in the context of their age-related changes (young rats were studied from five to eight months), the following conclusions can be drawn that, with age, the thickness of the interalveolar septum (TIS) and the width of the wire respiratory bronchioles (WRB). With an increase in the duration of experimental diabetes mellitus, the width of the conducting bronchioles (CB) increases. If on the 90th day of the experiment the BSB is $63.54 \pm 0.5 \mu \mathrm{m}$, then by $180-95.02 \pm 0.6 \mu \mathrm{m}$ (an increase of $49.5 \%$ ( $p \leq 0.001$ ). It was established that the presence of chronic hyperglycemia directly affects the hypertrophy of the interalveolar septum. TIS on the 90th day of the experiment is $7.03 \pm$ $0.1 \mu \mathrm{m}$, and already for 180 days $-15.02 \pm 0.04 \mu \mathrm{m}$ (an increase of 2 times). Conclusions. In this manner, under the conditions of experimental aloxane diabetes, thickening of the MI occurs, which can be linked to hyperplasia and hypertrophy of collagenous fibers; an increase in SBP, indicating bronchodilation and, mediated, of emphysematic changes in the lungs. That is, chronic hyperglycemia provokes the development of a violation of the respiratory act by the restrictive type with the parallel development of compensatory emphysema.

Вступ. За даними сучасної літератури [1-3] будова органів дихання вивчена досить досконало. Але незважаючи на те, що вплив екзогенних та ендогенних факторів на легені - це давня проблема, залишається багато невивчених питань щодо структурних змін легень за дії багатьох чинників. Достатньо речовин, які впливають на органи дихання, надходять і не через повітря, наприклад через шлунково-кишковий тракт або під впливом патологічних станів (хвороб), що відображається у нових наукових експериментах [4-11].

Одним $з$ актуальних чинників $є$ цукровий діабет, який на сьогоднішній день посідає третє місце після хвороб серцево-судинної системи та онкологічних захворювань. Загальновідомі патологічні зміни в органах-мішенях при хронічній гіперглікемії, але залишаються невивчені при цьому легеневі структури [12].

Тому, в нашій роботі ми проводили дослідження структур легень, а саме: товщини міжальвеолярної перегородки та ширини провідного відділу термінальної бронхіоли у щурів молодого віку.

Мета роботи - дослідити зміни структур легеневої тканини щурів прогресивного росту за умов експериментального алоксанового діабету.

Матеріал і методи. Дослідження проведені на 48 білих лабораторних щурах обох статей, масою $170,1 \pm 0,13$ г. Тварини були розподілені таким чином на групи (у кожній знаходилось по 6 особин) - 1-ша 3 терміном алоксанового діабету 90 діб, 2-га - 120 діб, 3-тя - 150 діб, 4-та - 180 діб. Кожна вищевказана експериментальна група порівнювалась з відповідною інтактною (табл.1).

Щури утримувались в умовах віварію кафедри морфології Медичного інституту СумДУ. Перед початком досліджень кожна група щурів проходила двотижневий карантин. Тварини доглядалися згідно з загальноприйнятими рекомендаціями, вимогами та положеннями щодо догляду за лабораторними тваринами («Правила проведення робіт з використанням експериментальних тварин», додаток 4, затверджений наказом Міністерства охорони здоров’я № 755 від 12

Таблиця 1

\section{Розподіл експериментального матеріалу}

\begin{tabular}{|c|c|c|}
\hline $\begin{array}{c}\text { Тривалість } \\
\text { алоксанового } \\
\text { діабету }\end{array}$ & $\begin{array}{c}\text { Кількість експериментальних } \\
\text { тварин }\end{array}$ & Кількість інтактних тварин \\
\hline 3 місяці & 6 & 6 \\
\hline 4 місяці & 6 & 6 \\
\hline 5 місяців & 6 & 6 \\
\hline 6 місяців & 6 & \\
\hline Всього по групах & 48 & \\
\hline
\end{tabular}


серпня 1997 р., «Про заходи щодо подальшого удосконалення організаційних форм роботи з використанням експериментальних тварин»; «Загальні етичні приципи експериментів на тваринах», ухвалені Першим Національним конгресом $з$ біоетики (Київ, 2001 р.); правила, затверджені комісією з питань біоетики Медичного інституту Сумського державного університету (протокол № 4 від 22 грудня 2009 р.; Гельсінкська декларація Генеральної асамблеї Всесвітньої медичної асоціації (2000); положення «Свропейської конвенції про захист хребетних тварин, які використовуються для експериментів та інших наукових цілей» (Страсбург, 1985). Порушень морально-етичних норм при проведенні науково-дослідницької роботи не було.

Для експериментального моделювання гіперглікемії, яка зумовлюється абсолютною недостатністю інсуліну в організмі, використовували хімічну сполуку - алоксан. Після 24-годинного голодування на тлі нормальних показників крові тваринам уводили підшкірно розчин дигідрату алоксану в дозі 20 мг на
100 г маси тіла в 0,1М цитратному буфері (pH 4,0). Щури у відповідних вікових групах знаходились у стані хронічної гіперглікемії від 30 до 180 діб (вік тварин - від 3 до 8 місяців). Забій шести щурів кожної вікової групи проводили кожні 30 днів шляхом розтину грудної клітки під внутрішньоочеревинним тіопентал-натрієвим наркозом.

Досліджували легеневу тканину, використовуючи гістологічне дослідження із забарвленням за Ван-Гізон, сканувальну електронну мікроскопію з морфометрією, яку проводили за допомогою програми Digimizer 2007. Вимірювали товщину міжальвеолярної перегородки в середній, найтоншій та найтовщій ділянках із подальшим розрахунком середнього розміру, а також ширину провідного відділу термінальної бронхіоли. Крім того, визначали рівень глюкози венозної крові за допомогою глюкозооксидазного тесту та глікозильованого гемоглобіну (HbA1c) на 90-ту добу експерименту для підтвердження наявності у тварин цукрового діабету. Усі отримані числові показники

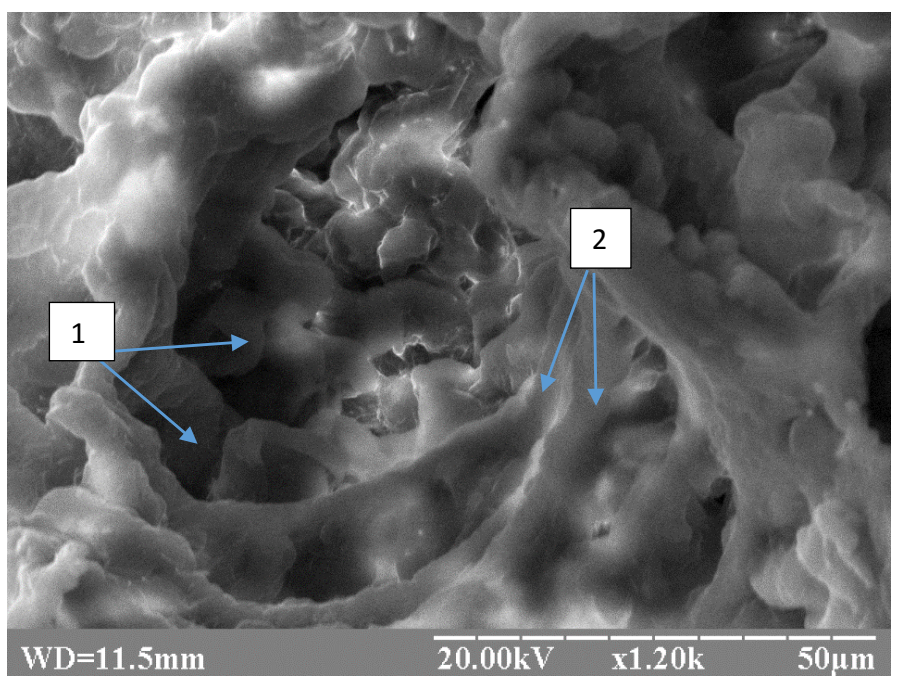

Рис. 1. Легенева тканина молодого щура інтактної групи (6 міс.). Сканувальна електронномікроскопічна фотографія. $\times 1200$

1 - порожнина альвеоли

2 - міжальвеолярні перегородки

Таблиця 2

Результати дослідження легень та лабораторні показники крові щурів молодого віку за умов експериментальної хронічної гіперглікемії

$(\mathrm{M} \pm \mathrm{m}), \mathrm{n}=\mathbf{6}$

\begin{tabular}{|c|c|c|c|c|c|c|c|c|}
\hline $\begin{array}{c}\text { Показ- } \\
\text { ник }\end{array}$ & $\begin{array}{c}\text { Інтактні } \\
\text { щури }\end{array}$ & $\begin{array}{c}90 \text { діб } \\
\text { ЦД }\end{array}$ & $\begin{array}{c}\text { Інтактні } \\
\text { щури }\end{array}$ & $\begin{array}{c}120 \text { діб } \\
\text { ЦД }\end{array}$ & $\begin{array}{c}\text { Інтактні } \\
\text { щури }\end{array}$ & $\begin{array}{c}150 \text { діб } \\
\text { Цд }\end{array}$ & $\begin{array}{c}\text { Інтактні } \\
\text { щури }\end{array}$ & $\begin{array}{c}180 \text { діб } \\
\text { ЦД }\end{array}$ \\
\hline $\begin{array}{c}\text { ШПБ, } \\
\text { мкм }\end{array}$ & $\begin{array}{c}60,02 \\
\pm 0,4 \\
\end{array}$ & $\begin{array}{c}63,54^{*} \\
\pm 0,5 \\
\end{array}$ & $\begin{array}{l}61,01 \\
\pm 0,7 \\
\end{array}$ & $\begin{array}{c}70,35^{*} \\
\pm 0,9 \\
\end{array}$ & $\begin{array}{c}67,04 \\
\pm 0,8 \\
\end{array}$ & $\begin{array}{c}78,01^{*} \\
\pm 0,5 \\
\end{array}$ & $\begin{array}{l}67,91 \\
\pm 0,5 \\
\end{array}$ & $\begin{array}{c}95,02^{*} \\
\pm 0,6 \\
\end{array}$ \\
\hline $\begin{array}{l}\text { ТМП, } \\
\text { мкм }\end{array}$ & $\begin{array}{c}5,4 \\
\pm 0,1 \\
\end{array}$ & $\begin{array}{l}7,03^{*} \\
\pm 0,1\end{array}$ & $\begin{array}{c}5,4 \\
\pm 0,1\end{array}$ & $\begin{array}{c}8,0^{*} \\
\pm 0,04\end{array}$ & $\begin{array}{l}6,08 \\
\pm 0,2\end{array}$ & $\begin{array}{l}9,02^{*} \\
\pm 0,04\end{array}$ & $\begin{array}{c}6,1 \\
\pm 0,1\end{array}$ & $\begin{array}{l}15,02^{*} \\
\pm 0,04\end{array}$ \\
\hline $\begin{array}{r}\text { ГК,м- } \\
\text { моль/л }\end{array}$ & $\begin{array}{c}5,4 \\
\pm 1,3\end{array}$ & $\begin{array}{l}8,3^{*} \\
\pm 0,3\end{array}$ & $\begin{array}{c}3,5 \\
\pm 0,1\end{array}$ & $\begin{array}{l}8,5^{*} \\
\pm 0,1\end{array}$ & $\begin{array}{c}6,0 \\
\pm 0,1\end{array}$ & $\begin{array}{l}8,7^{*} \\
\pm 0,1\end{array}$ & $\begin{array}{c}6,3 \\
\pm 0,1\end{array}$ & $\begin{array}{l}8,1^{*} \\
\pm 0,1\end{array}$ \\
\hline $\mathrm{HbA} 1 \mathrm{C}, \%$ & $\begin{array}{c}4,7 \\
\pm 0,6\end{array}$ & $\begin{array}{l}8,1^{*} \\
\pm 0,3\end{array}$ & $\begin{array}{c}4,0 \\
\pm 0,04\end{array}$ & $\begin{array}{l}8,6^{*} \\
\pm 0,1\end{array}$ & $\begin{array}{c}4,5 \\
\pm 0,04\end{array}$ & $\begin{array}{l}8,3^{*} \\
\pm 0,1\end{array}$ & $\begin{array}{c}5,1 \\
\pm 0,1\end{array}$ & $\begin{array}{l}7,05^{*} \\
\pm 0,1\end{array}$ \\
\hline
\end{tabular}

Примітка: * $\mathrm{p} \leq 0,001$ 
підлягали статистичній обробці з використанням персонального комп'ютера Acer та ліцензійованої програми-редактора електронних таблиць Excel XP пакета Microsoft Office 2013.

Результати дослідження та їх обговорення.

Проводячи аналіз отриманих даних щурів інтактної групи у розрізі їх вікових змін (проводили дослідження щурів молодого віку 3 п`яти до восьми місяців), можна дійти висновку, що з віком товщина міжальвеолярної перегородки (ТМП) та ширина провідного відділу респіраторної бронхіоли (ШПБ) збільшуються (рис.1).

Числові показники рівня глюкози крові у тварин, що перебували в експерименті, коливались від 8,1 ммоль/л до 8, ммоль/л, що свідчить про наявність гіперглікемії. Показники рівня глікозильованого гемоглобіну в них коливались від 7,05\% до 8,6\%, що вище нормальних показників практично у 2 рази і дає право стверджувати наявність цукрового діабету.

3 90-ї доби алоксанового діабету ТМП порівняно 3 інтактними щурами збільшується на $30 \%$ ( $\mathrm{p} \leq 0,001)$. Протягом експерименту зберігається така тенденція
- зі збільшенням терміну цукрового діабету відбувається потовщення МП. Зростання показника з 90-ї по 180-ту добу тривання хронічної гіперглікемії відбувається у 2 рази.

У ході експерименту на 90-ту добу відзначаються ознаки бронходилатації, що статистично достовірно порівняно з інтактною групою (рис.2). Також простежується наступна тенденція: зі збільшенням терміну експериментального цукрового діабету, збільшується і ширина ПБ. Якщо на 90-ту добу експерименту ШПБ становить $63,54 \pm 0,51$ мкм, то вже на 180 -ту - 95,02 $\pm 0,6$ мкм (зростання показника на 49,5\% (p $\leq 0,001)$.

Збільшення ТМП можна пов'язати зі збільшенням кількості колагенових волокон, які є в її складі, що відбувається в інтактних щурів при дорослішанні, а в умовах експериментального алоксанового діабету цей процес посилюється (рис.3).

Разом 3 цим, виявляється, що при хронічній гіперглікемії паралельно розвиваються емфізематозні зміни в легенях, про що свідчить збільшення розмірів ШПБ.
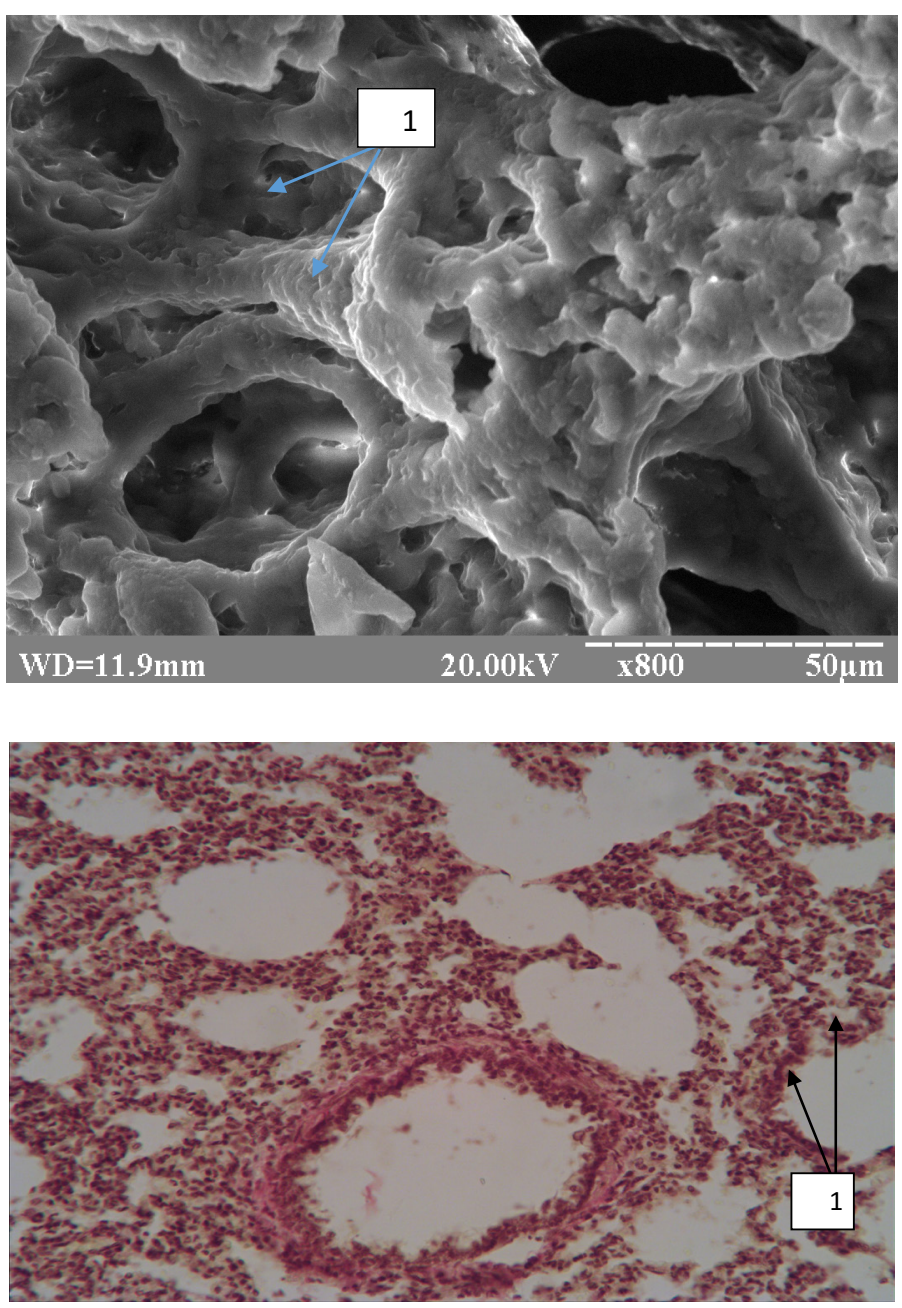

Рис.2. Легенева тканина щура молодого віку на 120-ту добу експерименту. Сканувальна електронномікроскопічна фотографія. $\times 800$

1 - термінальні бронхіоли

Рис.3. Легенева тканина щура молодого віку на 180-ту добу експерименту. Забарвлення за ВанГізон. $\times 100$ 1 - гіперплазія зрілих колагенових волокон у МП 
Висновки. Таким чином, за умов експериментального алоксанового діабету виникає потовщення міжальвеолярних перегородок, що можна пов'язати 3 гіперплазією та гіпертрофією колагенових волокон; збільшення ширини провідного відділу респіраторної бронхіоли, що говорить про бронходилатацію та, опосредковано, про емфізематозні зміни у легенях. Тобто, хронічна гіперглікемія провокує розвиток порушення дихального акту за рестриктивним типом 3 паралельним розвитком компенсаторної емфіземи.

Перспективи подалыших досліджень. Наступним етапом дослідження морфології легеневих структур під впливом експериментальної гіперглікемії $є$ проведення ультрамікроморфометрії з визначенням змін у аерогематичному бар єрі та альвеолоцитах.

\section{Список літератури}

1. Соколов ВВ. Современные представления о сегментарном строении легких. Эндоскопия. 2012; 2:17-20.

2. Сапрыкина ВП, Лесли П.Гартнер. Цветной атлас гистологии: Москва: Логосфера; 2008. 464 с.

3. Козлов АЕ. Функции белков сурфактанта в легких. Bulletin of Medical Internet Conferences. 2015; 5: 1648.

4. Мороз ГА. Фармкоррекция морфофункциональных нарушений в органах эндокринной и иммунной систем, вызванных систематическим воздействием гравитационных перегрузок. Світ медицини та біології. 2013; 2:62-63.

5. Макарова ОІ. Гістологічні особливості легень щурів, яким протягом перших 7 діб вводили розчин лактопротеїну 3 сорбітолом, через 14, 21 і 30 діб після опікової травми. Молодий вчений. 2014; 8 (11):118-121.

6. Ибраев СА. Морфологические изменения легких при воздействии промышленной хризотилсодержащей пыли. Science and healthcare. 2015; 2: 30-35.

7. Samara Katerina D. Smoking and pulmonary fibrosis. Pulmonary medicine. 2011; 2011: 1-4.

8. Roan E. What do we know about mechanical stresses in the lung's alveoli?. American journal of physiology. 2011; 5(305): 25-35.

9. Waters Erica A. Concern about unintended negative consequences of informing the public about multifactorial risk may be premature for young adult smokers. Helth psychology. 2014; 19(4): 720-736.

10. Saglam Melda. Functional. Functional capacity, physical activity, and quality of life in hypoxemic patients with chronic obstructive pulmonary disease. International Journal of COPD. 2016; 10: 423-428.

11. Yu-Hsiang Hsu. Interleukin-20 targets podocytes and is upregulated in experimental murine diabetic nephropathy. Experimental \& Molecular Medicine. 2017; 49: 1-11.
12. Степанян ИЭ. Особенности заболеваний легких при сахарном диабете. Атмосфера. Пульмонология и аллергология. 2009; 4: 8-10.

\section{References}

1. Sokolov VV. Sovremennye predstavlenija o segmentarnom stroenii legkih [Modern ideas about the segmental structure of the lungs]. Jendoskopija. 2012; 2:17-20. (in Russian).

2. Saprykina VP, Lesli P.Gartner. Cvetnoj atlas gistologii[Color atlas of histology]: Moskva: Logosfera; 2008. 464 s. (in Russian).

3. Kozlov AE. Funkcii belkov surfaktanta v legkih [Functions of surfactant proteins in the lungs]. Bulletin of Medical Internet Conferences. 2015; 5: 1648. (in Russian).

4. Moroz GA. Farmkorrekcija morfofunkcional'nyh narushenij $\mathrm{v}$ organah jendokrinnoj i immunnoj sistem, vyzvannyh sistematicheskim vozdejstviem gravitacionnyh peregruzok [Pharmacorrection of morphofunctional disorders in the organs of the endocrine and immune systems caused by the systematic action of gravitational overloads]. Svit medicini ta biologiï. 2013; 2:62-63. (in Russian).

5. Makarova OI. Histolohichni osoblyvosti lehen' schuriv, yakym protiahom pershykh 7 dib vvodyly rozchyn laktoproteinu z sorbitolom, cherez 14, 21 i 30 dib pislia opikovoi travmy [Histological features of lungs of rats, which during the first 7 days were injected lactobacillus solution with sorbitol after 14, 21 and 30 days after burn injury]. Molodyi vchenyi. 2014; 8 (11):118-121.(in Ukrainian).

6. Ibraev SA. Morfologicheskie izmenenija legkih pri vozdejstvii promyshlennoj hrizotilsoderzhashhej pyli [Morphological changes in the lungs when exposed to industrial chrysotile-containing dust.]. Science and healthcare. 2015; 2: 30-35. (in Russian).

7. Samara Katerina D. Smoking and pulmonary fibrosis. Pulmonary medicine. 2011; 2011: 1-4.

8. Roan E. What do we know about mechanical stresses in the lung's alveoli?. American journal of physiology. 2011; 5(305): 25-35

9. Waters Erica A. Concern about unintended negative consequences of informing the public about multifactorial risk may be premature for young adult smokers. Helth psychology. 2014; 19(4): 720-736.

10. Saglam Melda. Functional capacity, physical activity, and quality of life in hypoxemic patients with chronic obstructive pulmonary disease. International Journal of COPD. 2016; 10: 423-428.

11. Yu-Hsiang Hsu. Interleukin-20 targets podocytes and is upregulated in experimental murine diabetic nephropathy. Experimental \& Molecular Medicine. 2017; 49: 1-11.

12. Stepanjan IJe. Osobennosti zabolevanij legkih pri saharnom diabete [Features of lung diseases in diabetes mellitus.]. Atmosfera. Pul'monologija i allergologija. 2009; 4: 8-10. (in Russian).

\section{Відомості про автора:}

Теслик Т.П.- аспірант кафедри морфології медичного інституту Сумського державного університету, м.Суми, Україна.

\section{Сведения об авторе:}

Теслык Т. П.- аспирант кафедры морфологии медицинского института Сумского государственного университета, г. Сумы, Украина.

\section{Information about the author:}

Teslyk T.P. - post-graduate student of the Department of Morphology of the Medical Institute of Sumy State University, Sumy, Ukraine.

Надійила до редакції 15.03.2018 